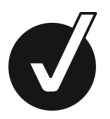

EDITOR'S

CHOICE
${ }^{1}$ University of South Dakota Sanford School of Medicine, Sioux Falls, South Dakota, USA ${ }^{2}$ Department of Pulmonary \& Sleep Medicine, Avera Medical Group, Sioux Falls, South Dakota, USA

${ }^{3}$ Department of Internal Medicine, University of South Dakota Sanford School of Medicine, Sioux Falls, South Dakota, USA

\section{Correspondence to} Dr Fady Jamous,

fady.jamous@avera.org

Accepted 8 January 2015
CrossMark

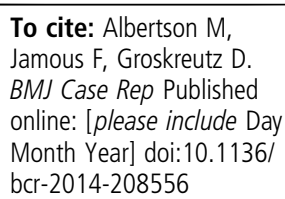

\title{
Expansive pulmonary artery aneurysm in an IV drug user
}

\author{
Megan Albertson, ${ }^{1}$ Fady Jamous, ${ }^{2,3}$ Dayna Groskreutz ${ }^{2}$
}

\section{DESCRIPTION}

A 46-year-old male with a history of IV drug use (methamphetamine and heroin) presented with upper respiratory complaints. His chest X-ray (figure 1A, B) showed increased fullness in the area of the pulmonary artery. The successive chest CT (figure $2 \mathrm{~A}, \mathrm{~B}$ ) showed a large aneurysm measuring $72 \times 77 \mathrm{~mm}$ without evidence of chronic thrombus or advanced lung disease. An echocardiogram demonstrated a severely enlarged right ventricle but
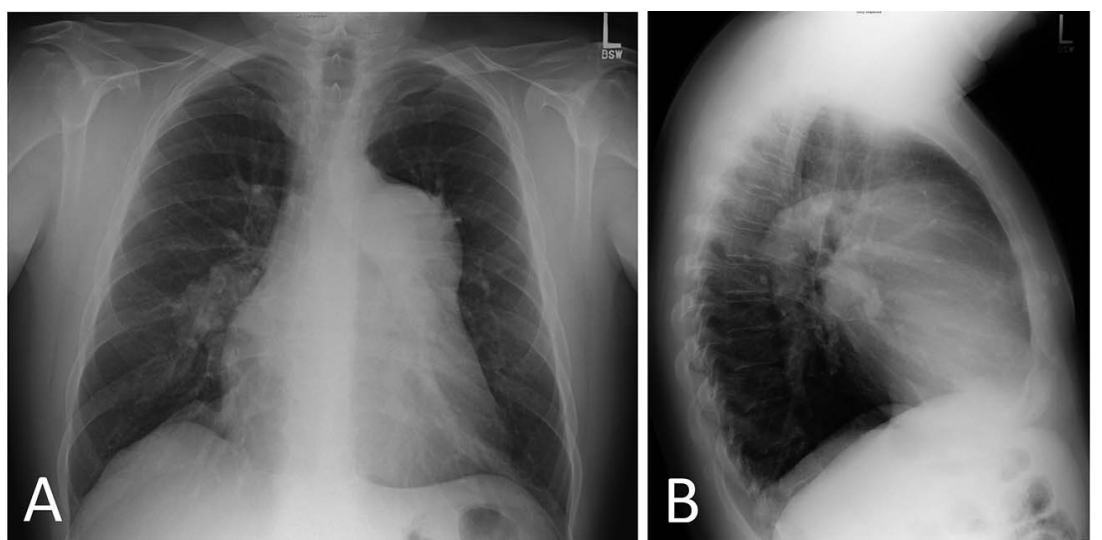

Figure 1 Posterior-anterior $(A)$ and lateral $(B)$ chest X-ray demonstrating an enlarged pulmonary artery in the left mediastinum.
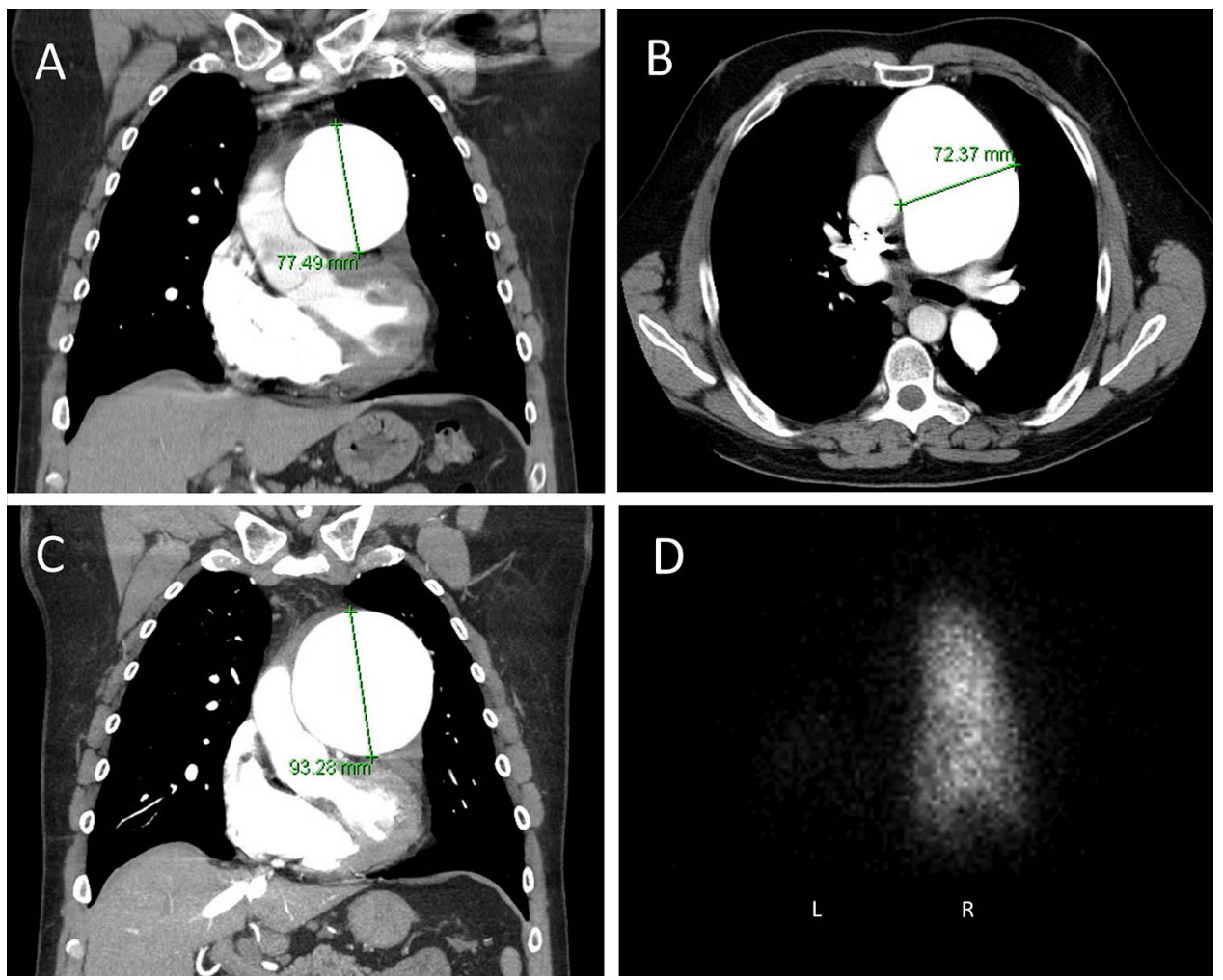

Figure 2 Initial chest computed tomography angiography scan (CTA) in coronal (A) and axial (B) views with a profoundly enlarged pulmonary trunk aneurysm. Repeat chest CTA (C) 2 years later shows dilatation of the pulmonary trunk aneurysm increased by $16 \mathrm{~mm}$. A posteriorly oriented ventilation-perfusion (VQ) scan image (D) demonstrates significantly impaired ventilation of the left lung. 
was otherwise unremarkable. Cardiac catheterisation revealed a mean pulmonary artery pressure of $49 \mathrm{~mm} \mathrm{Hg}$, a low left ventricular end diastolic pressure (LVEDP) of $6 \mathrm{~mm} \mathrm{Hg}$ and no evidence of intracardiac shunting. Polysomnography showed severe obstructive sleep apnoea. The patient was in prison at the time of diagnosis and was released shortly after the initial work-up. He had intermittent follow-up due to compliance issues and eventually presented 2 years later with increased dyspnoea. A repeat chest CT (figure 2C) showed expansion of the aneurysm to $90 \times 93 \mathrm{~mm}$ with compression of the left bronchus. This

\section{Learning points}

- Pulmonary artery aneurysms (PAAs) are rare but some evidence supports surgical intervention when dilation is $>6 \mathrm{~cm}$, or the patient is symptomatic; less severe cases tend to have a lower risk of rupture, leading some to recommend annual monitoring.

- PAAs often are discovered incidentally and have historically only been diagnosed on autopsy due to their high mortality.

- Because of their poor prognosis, it is important to fully investigate and treat the underlying cause of the PAA.

- Aetiologies include pulmonary hypertension, congenital heart disease, vasculitis, infection, IV drug use, connective tissue disease and trauma/iatrogenic causes.

- The effectiveness of medical management of pulmonary hypertension (such as vasodilator therapy) in minimising progression has not been fully studied due to the rarity of the condition. was also demonstrated on the ventilation portion of a ventilation-perfusion (VQ) scan (figure 2D). The patient began medical therapy and was pursuing surgical repair, but unfortunately died of a sudden cardiac event before intervention.

Pulmonary artery aneurysms (PAAs) are defined as dilatation of the vessel beyond $4 \mathrm{~cm}$ in diameter and are classified as central $(80 \%)$ or peripheral $(20 \%) .{ }^{1}$ Common causes of PAAs are pulmonary hypertension, congenital heart disease, pulmonary stenosis, trauma and vasculitis. ${ }^{2} 3$ Associated symptoms may include haemoptysis or dyspnoea as in our case. Pulmonary angiograms are the gold standard for diagnosis and cardiac catheterisation is often used to confirm the underlying aetiology. ${ }^{12}$ Treatments include medical therapy alone or surgery, which is usually recommended for patients who are symptomatic or have aneurysms $>6 \mathrm{~cm}$ in diameter. ${ }^{1}$

Contributors MA wrote the manuscript. DG provided insight into the content and the management of the patient. FJ was the attending physician of the patient and provided the revisions requested by the reviewers.

Competing interests None.

Patient consent Obtained.

Provenance and peer review Not commissioned; externally peer reviewed.

\section{REFERENCES}

1 Theodoropoulos $\mathrm{P}$, Ziganshin BA, Tranquilli $\mathrm{M}$, et al. Pulmonary artery aneurysms: four case reports and literature review. Int J Angiol 2013;22:143-8.

2 Araujo I, Escribano P, Lopez-Gude MJ, et al. Giant pulmonary artery aneurysm in a patient with vasoreactive pulmonary hypertension: a case report. BMC CardiovasC Disord 2011;11:64.

3 Nguyen ET, Silva Cl, Seely JM, et al. Pulmonary artery aneurysms and pseudoaneurysms in adults: findings at $\mathrm{CT}$ and radiography. AJR Am J Roentgenol 2007;188:126-34.

Copyright 2015 BMJ Publishing Group. All rights reserved. For permission to reuse any of this content visit

http://group.bmj.com/group/rights-licensing/permissions.

BMJ Case Report Fellows may re-use this article for personal use and teaching without any further permission.

Become a Fellow of BMJ Case Reports today and you can:

- Submit as many cases as you like

- Enjoy fast sympathetic peer review and rapid publication of accepted articles

- Access all the published articles

- Re-use any of the published material for personal use and teaching without further permission

For information on Institutional Fellowships contact consortiasales@bmjgroup.com

Visit casereports.bmj.com for more articles like this and to become a Fellow 